\title{
PELATIHAN PEMANFAATAN SAMPAH DAPUR SEBAGAI BAHAN PEMBUATAN PUPUK ORGANIK CAIR (POC) BAGI ANGGOTA RELAWAN LEMBAGA LINGKUNGAN HIDUP DAN PENANGGULANGAN BENCANA KABUPATEN BANYUMAS
}

\author{
Dini Nur Afifah ${ }^{1}{ }^{*}$, Pujiati Utami ${ }^{1}$, Suwarti ${ }^{1}$, Endar Puspawiningtiyas ${ }^{1}$, \\ Itsna Nurrahma Mildaeni' ${ }^{1}$, Yeti Rusmiati Hasanah ${ }^{1}$, Adam Mufarij ${ }^{1}$ \\ ${ }^{1}$ Universitas Muhammadiyah Purwokerto, Banyumas, Indonesia \\ *dini.nurafifah@ump.ac.id
}

\begin{abstract}
Abstrak: Pengelolaan sampah dapur merupakan salah satu upaya untuk mengurangi volume sampah yang masuk ke Tempat Pembuangan Sampah Akhir (TPA). Namun, hal tersebut masih jarang dilakukan oleh masyarakat. Rendahnya minat masyarakat dalam mengolah sampah disebabkan oleh: keterbatasan lahan, kerumitan proses, pengetahuan yang terbatas, dan kesibukan. Merujuk pada masalah tersebut, maka dalam pengabdian masyarakat ini ditawarkan pemanfaatan sampah rumah tangga sebagai bahan pupuk organik cair (POC). Inovasi yang dihadirkan adalah pemanfaatan kotoran sapi dan urin kambing untuk meningkatkan nutrisi POC. Sasaran kegiatan ini adalah anggota relawan Lembaga Lingkungan Hidup dan Penanggulangan Bencana (LLHPB) Banyumas. Tujuan kegiatan ini adalah mengedukasi mitra sasaran agar dapat menerapkan sistem pengolahan sampah secara benar dan ramah lingkungan melalui konversi sampah dapur menjadi POC dengan decomposer EM-4. Pengetahuan dan teknologi ditransfer melalui simulasi ipteks dengan sosialisasi daring, video tutorial, dan poster yang berkaitan dengan tema yang dipilih. Hasil evaluasi menunjukkan bahwa kegiatan IbM ini mampu meningkatkan kesadaran anggota mitra untuk mengolah sampah sebesar 91,7\%. Pupuk Organik Cair yang dibuat dengan teknik yang diusulkan memiliki kadar nitrogen, fosfor, dan kalium masing-masing sebesar 3,3\%; 6,2\% dan 7,8\%. Nilai tersebut telah sesuai dengan syarat mutu kadar N,P,K yang diatur dalam Peraturan Menteri Pertanian Nomor 70/Permentan/SR.140/10/2011.
\end{abstract}

Kata Kunci: sampah organik, pengomposan, pupuk organik cair

\begin{abstract}
Kitchen waste management is one of the efforts to reduce the volume of waste that enters final disposal sites. Unfortunately, this is still rarely done by people. A low interest of the people in processing waste is caused by: limited land, the complexity of the process, limited knowledge, and business. Referring to this problem, in this community service program, the use of household waste as liquid organic fertilizer (LOF) is offered. The innovation presented in this program is the uses of cow dung and goat urine to increase POC nutrition. The partner of this program was a volunteer member of the Banyumas Institute for the Environment and Disaster Management. The objective is to educate partners to implement a proper and environmentally friendly waste management system through the conversion of kitchen waste into POC with the EM-4 decomposer. Methods used in this program were science and technology simulation, through: online outreach, video tutorials, and posters related to the chosen theme, and the transfer of knowledge and technology. The evaluation results show that this program is able to increase the awareness of partner members to process waste by 91.7\%. Liquid Organic Fertilizer made by the proposed technique comprises nitrogen 3.3\%, phosphorus $6.2 \%$, and potassium $7.8 \%$. This value is in accordance with the quality requirements for the levels of $N, P$, K regulated in the Regulation of the Minister of Agriculture Number 70/Permentan/ SR. 140/10/2011
\end{abstract}

Keywords: organic waste, composting, liquid-organic fertilizer

\section{Pendahuluan}

Banyumas merupakan salah satu Kabupaten di Provinsi Jawa Tengah. Wilayah administratif Banyumas berada pada persimpangan perhubungan lintas daerah kota besar di Jawa Barat, Yogyakarta, dan Jawa Timur. Letak geografis yang strategis tersebut menyebabkan jumlah penduduk di Banyumas mengalami pertumbuhan yang pesat. Berdasarkan data Biro Pusat Statistik 
(BPS) jumlah penduduk Banyumas pada tahun 2020 mencapai 1.776.918 jiwa (BPS Kabupaten Banyumas, 2020). Pertumbuhan penduduk yang pesat tentunya membawa dampak positif dan negatif. Dampak positif yang dirasakan masyarakat adalah meningkatnya nilai investasi di Kabupaten Banyumas. Berdasarkan data Dinas Penanaman Modal dan pelayanan Satu Pintu (DPMPTSP), nilai investasi di Kabupaten Banyumas mencapai 1,077 triliun di tahun 2020. Nilai investasi tersebut didominasi oleh sektor tersier seperti perdagangan, restoran, hotel, transportasi, telekomunikasi, dan lain sebagainya (Fakhrudin, 2021).

Pertumbuhan manusia dan investasi di suatu wilayah ternyata dapat berdampak negatif pada peningkatan volume sampah dari tahun ke tahun. Hasil penelitian Widiyanto et al. (2017) menunjukkan bahwa laju produksi sampah di Kabupaten Banyumas adalah sebesar 2,064 liter/hari/orang. Jika jumlah penduduk saat ini mencapai 1.776.918 jiwa, maka volume sampah yang dihasilkan dalam setahun adalah $3.667 .559 \mathrm{~m}^{3}$. Jumlah tersebut tentu saja akan semakin meningkat dari tahun ke tahun. Disisi lain, Kabupaten Banyumas saat ini mengalami kesulitan dalam penyediaan tempat pembuangan sampah akhir (TPA). TPA Kabupaten Banyumas saai ini adalah TPA Gunung Tugel. Namun akibat volume sampah yang telah melebihi kapasitas, hanya $10,85 \%$ sampah yang dapat terangkut, sedangkan sebanyak $89,15 \%$ sisanya masih perlu mendapat perhatian. Langkah yang telah ditempuh oleh Pemda Banyumas adalah membangun hangar TPST (Tempat Pembuangan Sampah Terpadu) di wilayah Kedungrandu Patikraja, TPST Ajibarang, dan TPST Sumbang. Walaupun telah dilakukan pembangunan hangar, masalah sampah diakui masih menjadi pekerjaan rumah bagi pemerintah. Hal tersebut dikarenakan laju produksi sampah yang lebih cepat dibandingkan proses perluasan hangar TPST.

Langkah awal yang dapat dilakukan untuk menyelesaikan masalah sampah adalah dengan melakukan karakterisasi terhadap sampah yang dibuang ke TPA. Studi literatur menunjukkan bahwa komposisi sampah di TPA didominasi oleh sampah organik $(63,59 \%)$. Sisanya adalah sampah anorganik sebanyak $36,41 \%$. Sampah anorganik terdiri dari $26,70 \%$ sampah anorganik recyclable dan 9,70\% sampah anorganik non-recyclable (Zahra \& Damanhuri 2011). Melalui data tersebut, diketahui bahwa sampah organik merupakan penyumbang terbesar pada volume sampah. Sampah organik di TPA biasanya berupa sampah dapur dan sampah daun. Sampah dapur dapat dikelompokkan ke dalam golongan yang lebih spesifik, yaitu sisa makanan (daging, ikan, dan sisa makanan lainnya), buah-buahan, dan sayur-sayuran. Komposisi sampah dapur ditunjukkan pada Gambar 1. Melalui data Gambar 1 tersebut, diperlukan upaya pengolahan sampah organik terutama limbah dapur pada skala rumah tangga untuk mengurangi volume sampah yang masuk ke TPA.

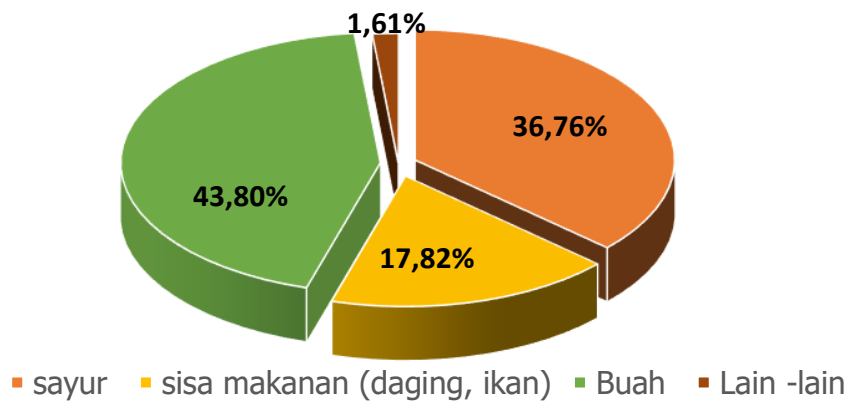

Gambar 1. Komposisi Sampah Organik (Zahra dan Damanhuri 2011) 
Berdasarkan uraian latar belakang masalah yang telah dijabarkan, maka tim Pengabdian Masyarakat melaksanakan kegiatan Iptek bagi Masyarakat (IbM) dalam wujud sosialisasi pengolahan sampah dapur menjadi Pupuk Organik Cair (POC). POC pada dasarnya merupakan larutan dari hasil pembusukan bahan-bahan organik. Kelebihan dari POC adalah tidak menyebabkan pencucian hara dan mampu menyediakan hara secara cepat. POC umumnya tidak merusak tanah dan tanaman walaupun sering digunakan. Selain itu pupuk POC juga memiliki bahan pengikat, sehingga larutan pupuk yang diberikan ke permukaan tanah dapat digunakan secara langsung (Nur et al., 2016).

Mitra yang dilibatkan pada pengabdian masyarakat dalam bentuk Iptek bagi Masyarakat (IbM) ini adalah grup relawan Lembaga Lingkungan Hidup dan Penanggulangan Bencana (LLHPB). LLHPB merupakan lembaga dibawah Pimpinan Daerah 'Aisyiyah (PDA) Banyumas. Sesuai dengan namanya, lembaga ini memiliki program kerja yang berfokus pada bidang konservasi lingkungan dan penanganan bencana. Anggota Relawan LLHPB saat ini mencapai 80 orang yang tersebar di 27 Pimpinan Cabang 'Aisyiyah (PCA) di Kabupaten Banyumas. Mayoritas anggota Relawan LLHPB saat ini adalah ibu rumah tangga dengan usia diatas 40 tahun. Survei awal terkait pengelolaan sampah dilakukan melalui wawancara. Berdasarkan hasil survei diketahui bahwa masalah yang sering dihadapi kelompok mitra terkait pengelolaan sampah adalah terbatasnya armada pengangkut sampah. Hal ini utamanya terjadi pada mereka yang tinggal di daerah perkotaan. Kondisi demikian menyebabkan bak sampah warga tidak cukup menampung volume sampah. Tumpukan sampah tersebut kemudian menimbulkan bau tidak sedap, lingkungan menjadi kumuh, serta mendatangkan vektor penyakit seperti lalat, tikus, dan kecoa. Hal lain yang biasanya terjadi adalah tim pengangkut sampah kembali mencampur sampah organik dan anorganik yang telah dipisahkan warga. Akibatnya masyarakat merasa usaha pemilahan sampah yang telah dilakukan tidak memberikan manfaat. Selain itu, praktek membuang sampah pada bantaran atau tebing sungai juga masih banyak terjadi di lingkungan mitra. Selama ini informasi dalam bentuk berbagai pelatihan pengolahan sampah bagi ibu rumah tangga telah banyak disampaikan. Namun sayangnya, praktek pengolahan sampah masih tergolong rendah.

Melihat pada kondisi mitra, maka perlu diperkenalkan model pengolahan sampah rumah tangga yang mudah diaplikasikan di lingkup rumah tangga. Selain itu proses pengolahan sampah yang diperkenalkan sebaiknya menghasilkan sebuah produk bernilai ekonomis yang mampu menggugah minat ibu-ibu untuk mengolah sampah dapur. Merujuk pada kondisi tersebut, maka POC dari sampah rumah tangga dinilai cocok untuk diperkenalkan kepada kaum Ibu. Hal ini mengingat bahwa teknik pengomposan pada dasarnya tidaklah rumit. Produk yang dihasilkan juga dapat dimanfaatkan sebagai pengganti pupuk sintetik atau bahkan dijadikan peluang usaha di masa Pandemi Covid-19. POC pada IbM ini diproduksi melalui proses fermentasi sampah hijau dan coklat rumah tangga. Agen decomposer yang digunakan adalah EM-4 yang relatif mudah ditemukan dipasaran. Dalam rangka menambahkan kualitas produk POC, digunakan kotoran sapi dan urin kambing. Penambahan urin kambing dan kotoran sapi ini diharapkan dapat meningkatkan kadar fosfor, kalium dan nitrogen POC. Parameter kualitas produk POC yang digunakan Peraturan Menteri Pertanian Nomor 70/Permentan/SR.140/10/2011. 
Tujuan program IbM ini adalah untuk memberikan informasi kepada masyarakat mengenai teknik pengelolaan sampah organik yang dapat diterapkan pada lingkup rumah tangga mengedukasi mitra agar dapat menerapkan sistem pengolahan sampah secara benar dan ramah lingkungan melalui konversi sampah dapur menjadi POC dengan decomposer EM-4, dan meningkatkan keterampilan mitra dalam membuat POC yang dapat dimanfaatkan untuk meningkatkan produktivitas baik secara agronomi maupun ekonomi

\section{Metode}

Sasaran utama IbM ini adalah seluruh anggota Relawan LLHPB PDA Banyumas yang dilaksanakan dalam rentang waktu 4 bulan, yaitu pada periode April 2021 hingga Agustus 2021. Praktek pembuatan pupuk organik cair dilakukan di Kebun Percobaan, Fakultas Pertanian dan Perikanan Universitas Muhammadiyah Purwokerto. Pengujian sampel POC dilakukan di Laboratorium Teknik Kimia, Universitas Muhammadiyah Purwokerto. Sosialisasi pengolahan sampah dilakukan secara daring (online). Alat dan bahan khusus yang digunakan dalam pembuatan POC adalah sampah organik dapur, molase, urin kambing, pupuk kandang, dan EM-4. Rangkaian alat pengomposan ditunjukkan pada Gambar $\mathbf{2}$.

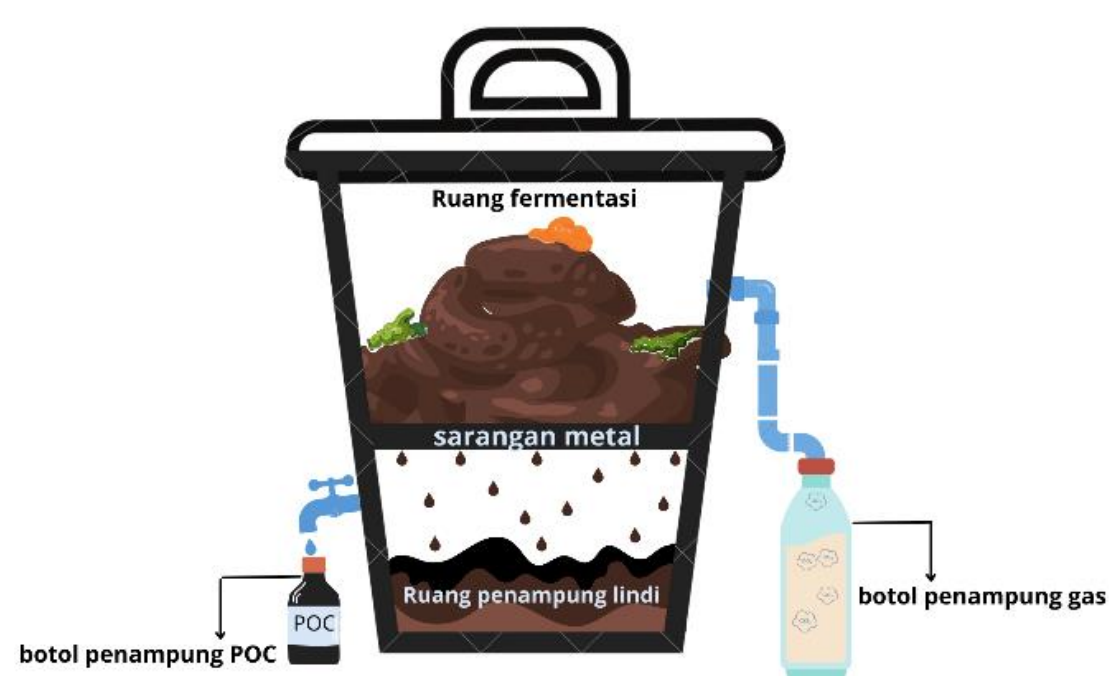

Gambar 2. Desain Komposter Sampah Dapur

Pelaksanaan kegiatan IbM ini dilakukan dalam beberapa tahap. Tahap pertama adalah uji coba teknik pembuatan POC dari sampah dapur. Tahap ini diilakukan dengan tujuan untuk menguji validitas prosedur pembuatan POC. Kegiatan ini dilaksanakan di Kebun Percobaan Fakultas Pertanian dan Perikanan, Universitas Muhammadiyah Purwokerto. Luaran pada tahap ini adalah Prosedur Pembuatan POC yang diolah ke dalam bentuk video tutorial pembuatan POC yang selanjutnya ditampilkan dan dibagikan kepada kelompok mitra pada kegiatan sosialiasi secara daring.

Tahap selanjutnya adalah menyelenggarakan Webinar dengan tema "Sosialisasi Pengolahan Sampah Dapur Menjadi POC". Sasaran dalam kegiatan ini adalah seluruh anggota Relawan Lembaga Lingkungan Hidup dan Penanggulangan Bencana (LLHPB) dan masyarakat umum. Materi yang disampaikan dalam sosialisasi terdiri dari dua jenis materi. Materi pertama bertajuk pengolahan sampah rumah tangga dengan teknik pengomposan. Materi kedua merupakan praktek 
virtual pengolahan sampah dapur menjadi POC. Tingkat keberhasilan kegiatan sosialisasi dinilai dari hasil pre-test dan post-test. Pembagian pre-test dan post-test dilakukan secara daring untuk mengukur tingkat pemahaman peserta kegiatan webinar terhadap materi yang disampaikan. Transfer informasi, pengetahuan, dan teknologi pada kegiatan IbM ini dilakukan melalui metode simulasi ipteks mengenai pengolahan sampah organik dapur dengan teknik fermentasi. Kerangka penyelesaian masalah ditampilkan pada Gambar 3.

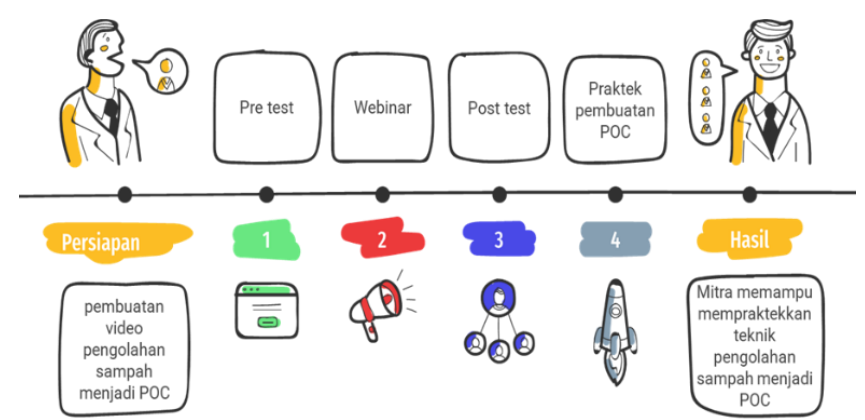

Gambar 3. Kerangka Penyelesaian Masalah

\section{Hasil dan Pembahasan}

\section{Penyusunan Metode Pembuatan POC dari Sampah Organik Rumah Tangga}

Pupuk organik cair (POC) adalah larutan hasil dari pembusukan bahan-bahan organik yang berasal dari sisa tanaman, kotoran hewan dan manusia yang kandungan unsur haranya lebih dari satu unsur. POC dapat diaplikasikan pada tanaman dengan cara disemprotkan langsung pada bagian daun sehingga lebih mudah diserap oleh tanaman. Penambahan POC pada tanaman dipercaya memberikan beberapa manfaat, seperti mempercepat tumbuhnya daun yang berperan dalam fotosintesis dan penyerapan nitrogen, memperkuat akar tanaman, serta merangsang pertumbuhan bunga dan bakal buah (Marpaung et al., 2016). Metode yang akan diperkenalkan kepada masyarakat telah diuji coba oleh tim Pelaksana IbM. Tahap ini melibatkan dosen pelaksana dan tim mahasiswa. Setiap tahapan proses didokumentasikan untuk dijadikan luaran IbM berupa video tutorial. Video tutorial pengolahan sampah dapur menjadi POC selanjutnya ditayangkan saat sosialisasi daring dan dibagikan kepada mitra melalui sosial media. Proses uji coba metode pembuatan POC ditampilkan pada Gambar 4.

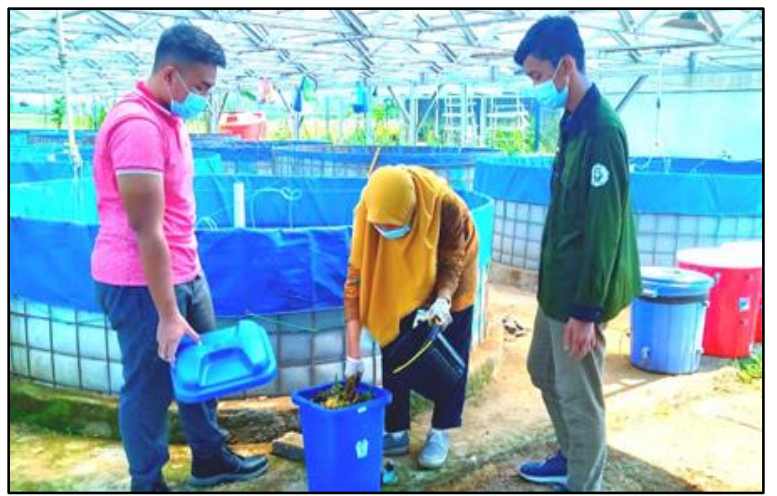

(a)

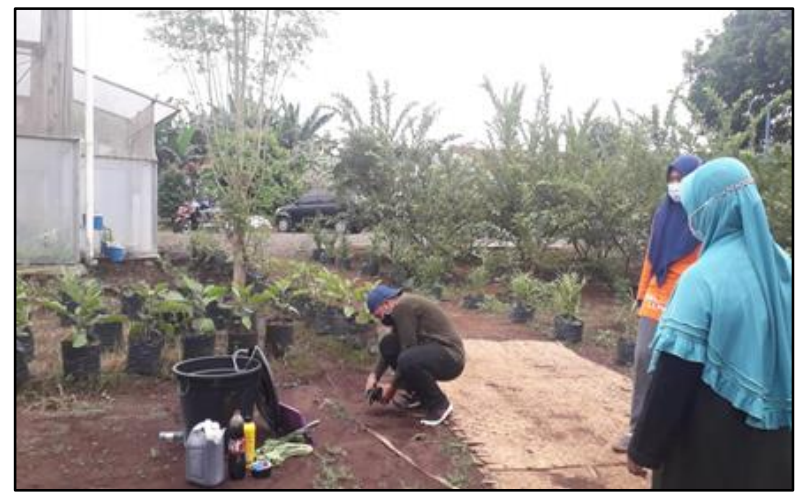

(b)

Gambar 4. (a) Praktek pembuatan POC bersama Mahasiswa (b). Pembuatan Video Tutorial Pengolahan Sampah Menjadi POC bagi Mitra 
Pengomposan sampah organik menjadi POC melibatkan beberapa bahan utama, yaitu sampah dapur, aktivator mikroba, dan larutan gula (Tanti et al., 2019; Rasmito et al., 2019. Selain bahan utama tersebut, pembuatan POC pada IbM ini melibatkan bahan baku tambahan lain guna menambah unsur hara produk POC. Bahan baku pembuatan POC pada IbM ini ditunjukkan pada

\section{Gambar 5.}

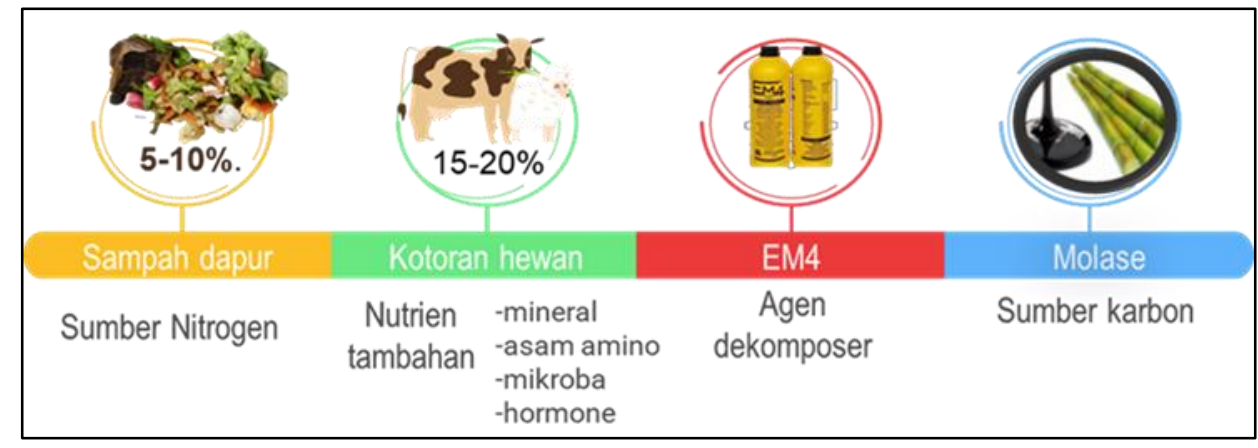

Gambar 5. Bahan Baku Pembuatan POC dari Sampah Dapur

Hal yang selama ini dikhawatirkan oleh mitra dalam pengomposan adalah munculnya bau tidak sedap selama proses fermentasi. Munculnya bau ini dapat disebabkan oleh beberapa hal. Hal pertama adalah kesalahan dalam pemilahan sampah. Pada dasarnya sampah dapur yang dapat difermentasi oleh mikroba adalah jenis sampah hijau dan sampah coklat. Sampah hijau terdiri dari sisa sayuran basah, sedangkan sampah coklat merupakan jenis ranting dan daun kering. Jenis sampah basah yang mengandung minyak tidak dianjurkan untuk dikomposkan. Hal ini karena minyak dapat menghambat proses fermentasi. Untuk memudahkan mitra dalam memilah sampah, maka dibuat poster mengenai jenis sampah yang dapat dikomposkan (Gambar 6). Hal kedua yang harus dihindari untuk mencegah timbulnya bau adalah jumlah sampah basah yang berlebihan. Hasil uji coba menunjukkan bahwa perbandingan sampah kering dan basah yang paling sesuai untuk pengomposan sampah organik dapur adalah 1:2 (b/b).

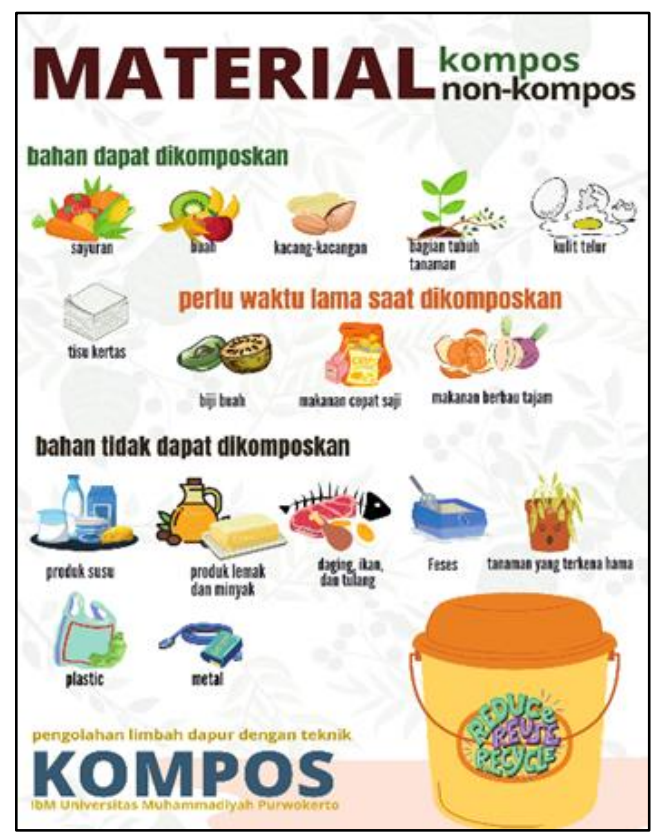

Gambar 6. Jenis Sampah untuk Kompos 
Bahan utama lain yang digunakan dalam proses pengomposan adalah mikroba. Mikroba dalam IbM ini diperoleh dari larutan effective microorganisms 4 (EM-4). Larutan EM-4 ini mengandung mikroba, seperti bakteri fotosintetik, Lactobacillus $s p$, Streptomyces $s p$, ragi (yeast), Actinomycetes yang memiliki kemampuan untuk menguraikan bahan organik. Fermentasi menggunakan EM-4 dilakukan secara anaerobik sehingga cocok diterapkan sebagai aktivator dalam pengomposan sampah skala rumah tangga (Subandriyo et al., 2012). Efektivitas proses pengomposan dapat ditingkatkan dengan menjaga kondisi optimum bagi pertumbuhan bakteri. salah satunya adalah dengan penambahan zat gula sebagai sumber karbon bagi pertumbuhan mikroba. Sumber karbon yang digunakan pada IbM ini adalah molase. Molase merupakan produk samping dari industri pembuatan gula yang mengandung sekitar $48-55 \%$ sukrosa. Selain sebagai sumber karbon, molase juga bermanfaat untuk menambah mineral, seperti Kalsium (Ca), Kalium $(\mathrm{K})$, Magnesium, Klor (Cl), dan Fosfor yang bermanfaat bagi tanaman (Nururrozi et al., 2017).

Pada penjelasan sebelumnya telah disebutkan bahwa molase mengandung mineral penting bagi tanaman. Namun sayangnya, kandungan fosfor pada molase masih cukup rendah, sehingga dalam IbM ini ditambahkan bahan baku lain untuk meningkatkan kadar fosfor pada produk POC. Menurut Nuryani et al. (2019), kandungan fosfor sangat diperlukan pada masa vegetatif tanaman. Hal ini karena mampu merangsang pertumbuhan akar, khususnya akar benih/tanaman muda, mempercepat serta memperkuat pertumbuhan tanaman muda menjadi tanaman dewasa serta menaikkan persentase bunga menjadi buah atau biji. Sumber fosfor yang digunakan pada IbM ini adalah pupuk organik dari feses sapi dan urin kambing. Kandungan Mineral pada kedua bahan tersebut ditunjukkan pada Tabel 1.

Tabel 1. Kandungan mineral pada kotoran Sapi dan Urin Kambing (Ginting, 2017)

\begin{tabular}{llllll}
\hline Jenis & $\mathrm{N}$ & $\mathrm{P}$ & $\mathrm{K}$ & $\mathrm{Ca}$ & $\mathrm{Mg}$ \\
\hline Kotoran sapi & $1,1 \%$ & $2,5 \%$ & $0,5 \%$ & $3 \%$ & $0,6 \%$ \\
Urin kambing & $1,47 \%$ & $0,05 \%$ & $1,96 \%$ & & \\
\hline
\end{tabular}

Tabel 1 menunjukkan bahwa kotoran sapi dan urin kambing mengandung berbagai mineral yang bermanfaat bagi pertumbuhan tanaman, terutama di masa vegetatif. Selain mineral, kotoran sapi dan urin juga diketahui memiliki kandungan asam amino dan hormon pertumbuhan yang dibutuhkan oleh tanaman (Sarah et al., 2016).

Hasil analisis kadar nitrogen, fosfot, dan kalium POC ditunjukkan pada Tabel 1 dan Tabel 2 menunjukkan bahwa produk POC IbM ini memenuhi standar tiga elemen dasar yang dianjurkan oleh Permentan Nomor 70 Tahun 2011, yaitu kadar nitrogen dan fosfor berkisar antara 3-6\%. Selain itu data analisis kimia pada Tabel 2 juga menunjukkan bahwa kadar nitrogen dan fosfor jauh meningkat dibandingkan POC yang dibuat dengan bahan baku yang sama namun tanpa penambahan urin kambing dan kotoran sapi.

Tabel 2. Perbandingan Kualitas POC dengan Referensi Sesuai Peraturan Menteri Pertanian Nomor 70/Permentan/SR.140/10/2011

\begin{tabular}{llccl}
\hline & $\mathrm{N}$ & $\mathrm{P}$ & $\mathrm{K}$ & Keterangan \\
\hline Referensi & $3-6 \%$ & $3-6 \%$ & $3-6 \%$ & Permentan Nomor 70 \\
& & & & Tahun 2011 \\
POC Hasil IbM & $3,3 \%$ & $6,2 \%$ & $7,8 \%$ & \\
POC dari penelitian lain & $0,205 \%$ & $0,0074 \%$ & $0,1138 \%$ & Nur dkk (2016) \\
\hline
\end{tabular}




\section{Sosialisasi pengolahan Sampah dengan Teknik Pengomposan}

Sosialisasi pengolahan sampah dapur dengan teknik pengomposan dilakukan secara daring dengan total peserta sebanyak 78 orang. Berdasarkan data kegiatan diketahui bahwa peserta yang terlibat dalam kegiatan ini terdiri dari dua golongan, yaitu anggota Corps Relawan LLHPB PDA Banyumas dan Mahasiswa Universitas Muhammadiyah Purwokerto. Data Demografi peserta kegiatan ditunjukkan pada Tabel 3.

Tabel 3. Demografi Sasaran IbM

\begin{tabular}{lcc}
\hline \multicolumn{1}{c}{ Demografi } & Jumlah & Presentase (\%) \\
\hline Jenis Kelamin & & \\
- Laki laki & 17 & 21,79 \\
- Perempuan & 61 & 78,20 \\
Organisasi & & \\
- Relawan LLHPB & 14 & 17,94 \\
- Non Relawan LLHPB & 64 & 82,05 \\
Pekerjaan & & \\
- Guru & 1 & 1,28 \\
- PNS & 2 & 2,56 \\
- BUMN & 1 & 1,28 \\
- Mahasiswa & 53 & 67,94 \\
- Ibu Rumah tangga & 21 & 26,92 \\
\hline
\end{tabular}

Tabel 3 menunjukkan bahwa mayoritas peserta dalam kegiatan sosialisasi pengolahan sampah dapur menjadi POC adalah dari kalangan mahasiswa, yaitu sekitar 82,05\%. Hal ini menunjukkan bahwa saat ini kalangan muda sudah mulai sadar akan isu lingkungan, terutama sampah. Selain diikuti oleh mahasiswa, kalangan yang dominan mengikuti kegiatan sosialisasi adalah kalangan ibu. Hal ini dapat dipahami karena mereka adalah golongan yang paling dekat hubungannya dengan kegiatan dapur. Golongan ibu rumah tangga yang mengikuti kegiatan sosialisasi ini seluruhnya merupakan anggota dari Relawan LLHPB. Dilihat dari nilai total, maka jumlah relawan LLHPB yang mengikuti kegiatan sosialisasi berjumlah 14 orang, atau sekitar 17,5\% dari total anggota Relawan LLHPB yang berjumlah 80 orang. Nilai presentase yang cukup kecil tersebut, karena mayoritas anggota Relawan LLHPB merupakan kalangan ibu-ibu dengan usia diatas 50 tahun yang tidak familiar dengan teknologi informasi, terutama sosialisasi daring. Mengantisipasi terjadinya hal tersebut, maka pada IbM ini telah disiapkan tutorial pembuatan POC dalam bentuk video yang dapat dengan mudah dibagikan melalui sosial media grup Relawan LLHPB. Cuplikan materi dalam bentuk video ditunjukkan pada Gambar 7. Sementara produk POC yang dihasilkan dalam kegiatan IbM ini ditunjukkan pada Gambar 8.

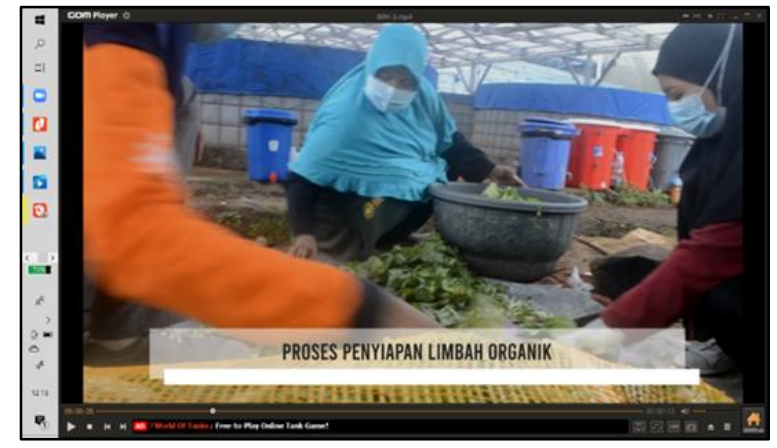

Gambar 7. Cuplikan Video Tutorial Pengomposan Sampah Organik Dapur 


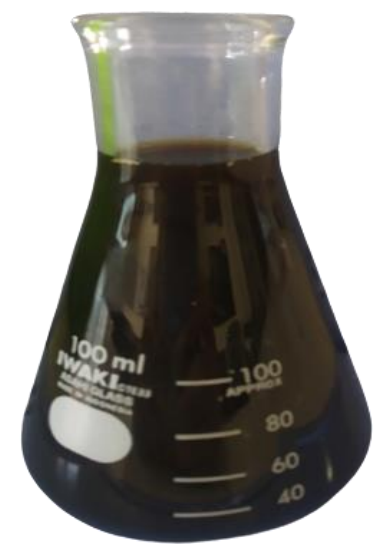

Gambar 8. Produk POC dari Limbah Organik Dapur

Data survei awal mengenai teknik pengolahan sampah yang dilakukan oleh kelompok sasaran disajikan pada Gambar 9.

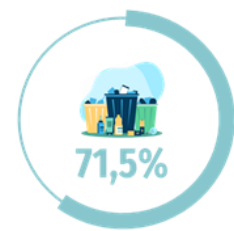

Dibuang ke TPA

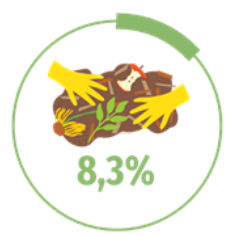

kompos

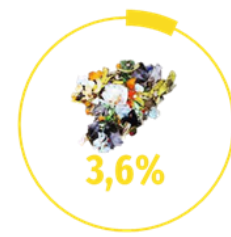

Dikubur

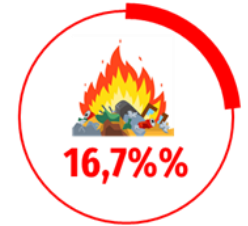

Dibakar

Sumber: Data Tim IbM

Gambar 9. Gambaran Awal Teknik Pengolahan Sampah oleh Kelompok Sasaran

Hasil survei tersebut menunjukkan bahwa mayoritas kelompok sasaran tidak mengolah sampah rumah tangganya sendiri. Kelompok sasaran yang melakukan pengolahan sampah mandiri hanya sekitar $28,6 \%$. Pengolahan sampah rumah tangga dilakukan dengan teknik pengomposan, penguburan, dan pembakaran. Presentasi untuk masing-masing teknik pengolahan sampah tersebut, yaitu: 8,3\%., 3,6\%, dan 16,7\%. Berdasarkan nilai tersebut, maka dapat disimpulkan bahwa belum banyak dari anggota kelompok sasaran yang tertarik untuk melakukan pengomposan sampah. Hal ini dapat dikarenakan beberapa alasan seperti yang ditunjukkan pada Gambar $\mathbf{1 0 .}$
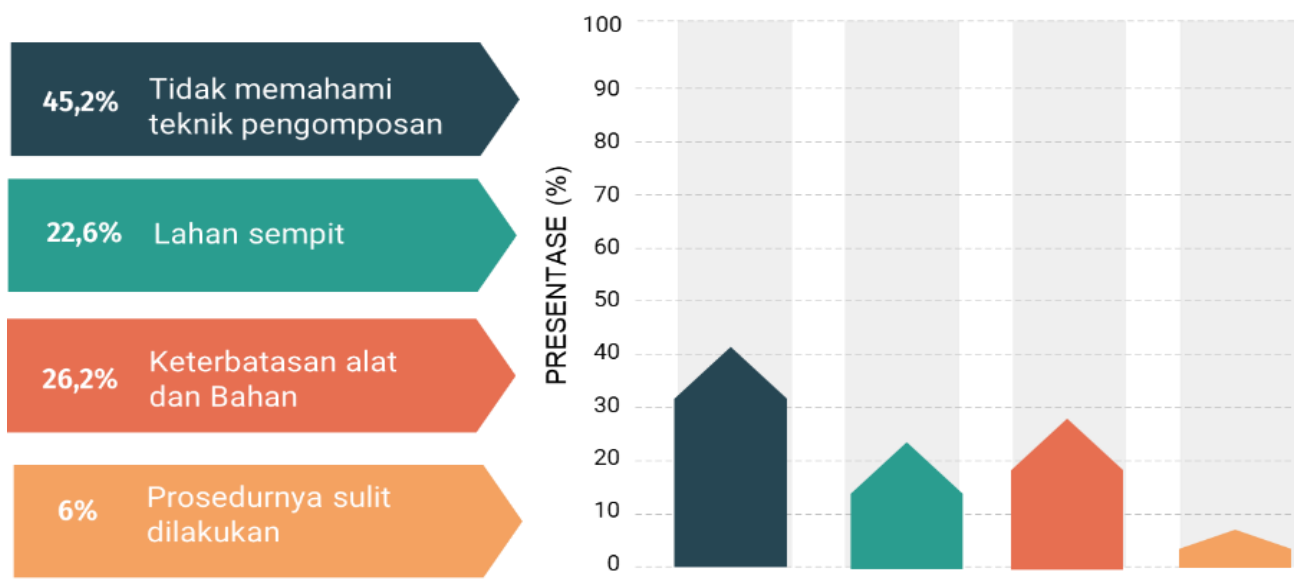

Gambar 10. Faktor Penghambat Pengolahan Sampah Rumah Tangga dengan Teknik Pengomposan

Data Gambar 10 menunjukkan bahwa faktor penghambat utama yang dirasakan oleh kelompok sasaran dalam pengomposan adalah tidak memahami tata cara pengomposan. 
Menanggapi data tersebut maka disusunlah dua materi yang berkaitan dengan teknik pengomposan sampah rumah tangga. Materi pertama tentang pengolahan sampah rumah tangga. Cakupan materi pertama ini adalah fakta sampah di Indonesia, pengomposan sampah organik, dan potensi sampah menjadi produk ekonomis. Materi kedua adalah praktek virtual teknik produksi POC dari sampah rumah tangga. Pada sesi kedua ini disajikan penjelasan umum mengenai POC, manfaat POC, kelebihan dan kekurangan pembuatan POC, nilai ekonomis POC, serta prosedur pembuatan POC dari sampah dapur. Sesi penyampaian materi ditampilkan pada Gambar 11.

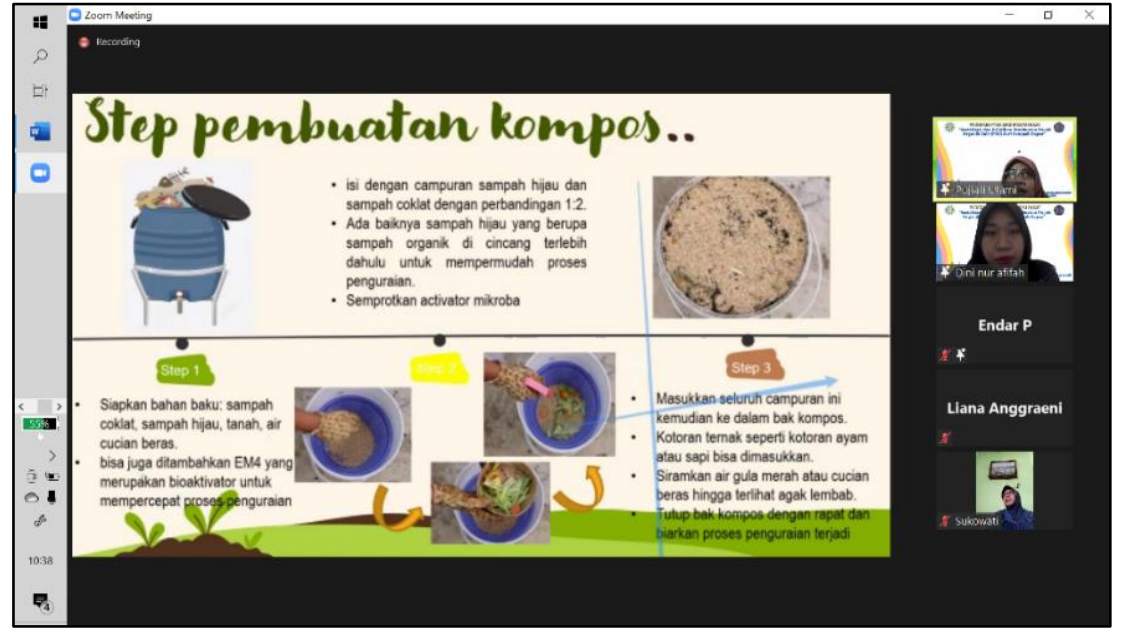

Gambar 11. Penyampaian Materi Pengolahan Sampah Dapur Menjadi POC secara Daring

Tingkat pemahaman peserta kegiatan terhadap materi yang disampaikan dalam sosialisasi dievaluasi dari hasil pre-test dan post test. Bentuk pertanyaan yang diberikan dalam pre-test dan post test berkaitan dengan isi materi sosialisasi seperti fungsi perlakuan, manfaat bahan pendukung, dan tata cara prosedur pembuatan POC. Rangkuman nilai pre-test dan post-test ditampilkan pada Tabel 4.

Tabel 4. Perbandingan Statistika Pre-test dan Post-test Peserta Kegiatan IbM

\begin{tabular}{lccccc}
\hline & N & Min & Max & Mean & SD \\
\hline Pre-test & 78 & 15 & 100 & 48 & 22 \\
\hline Post-test & 78 & 30 & 100 & 80 & 20 \\
\hline
\end{tabular}

Data pada Tabel 4 menunjukkan bahwa terdapat peningkatan kualitas pemahanan sasaran terhadap materi yang disampaikan. Skor minimal sebelum mengikuti sosialisasi adalah 15, sedangkan setelah mengikuti sosialisasi skor minimal menjadi 30. Rata-rata skor secara keseluruhan juga menunjukkan peningkatan yang cukup signifikan, yaitu dari 48 menjadi 80 . Hal ini menunjukkan bahwa peserta kegiatan sudah cukup memahami teknik pengolahan sampah dengan teknik pengomposan. Terlebih dari itu, mereka sudah mampu mempraktekkan pembuatan POC pada skala rumah tangga. Setelah mengikuti sosialisasi IbM sebanyak $100 \%$ peserta kegiatan juga menyatakan tertarik untuk mencoba teknik pengomposan di lingkup rumah tangga. Hasil tersebut menunjukkan bahwa minat kelompok sasaran untuk mengolah sampah menjadi kompos meningkat sebesar $91,7 \%$. 


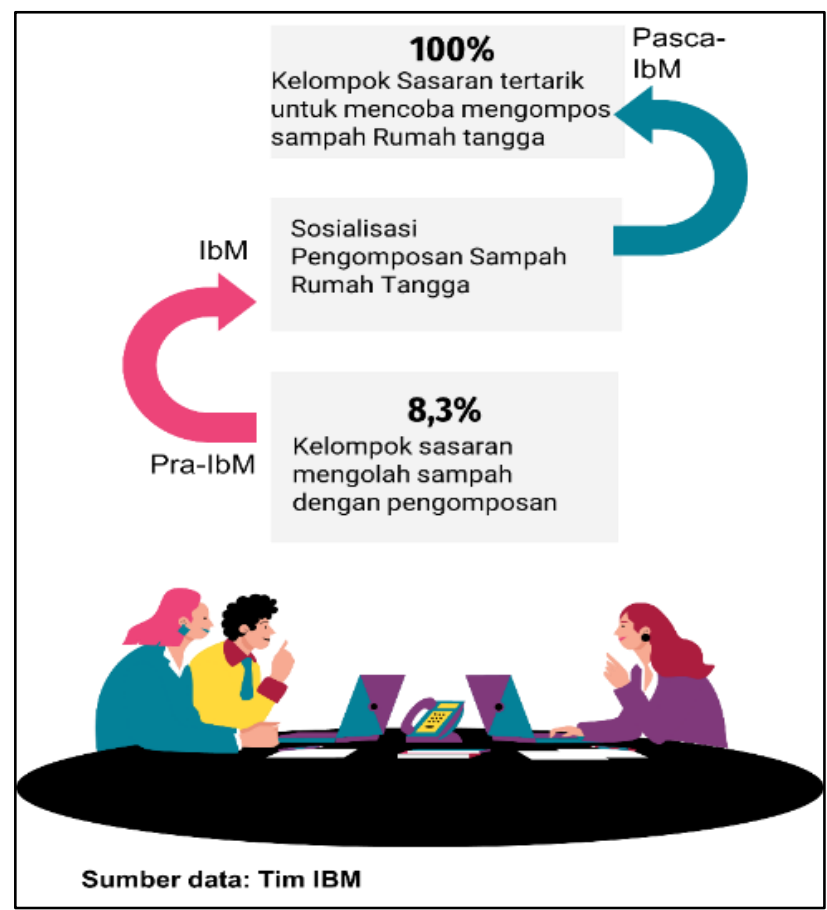

Gambar 12. Hasil Survei Mengenai Ketertarikan Mengolah Sampah dengan Pengomposan

\section{Kesimpulan}

Kesadaran kelompok sasaran dalam mengolah sampah rumah tangga meningkat hingga $91,7 \%$ setelah mengikuti kegiatan IbM ini. Nilai evaluasi dalam bentuk post test menunjukkan bahwa rata-rata skor pemahaman sasaran terhadap isi materi adalah 80 . Skor rata-rata ini meningkat cukup signifikan dibandingkan sebelum dilakukan penyuluhan yang hanya sebesar 48. Selain itu, seluruh kelompok sasaran menyatakan bahwa pengolahan sampah secara mandiri penting untuk dilakukan. Produk akhir dari kegiatan IbM ini adalah POC dengan kadar nitrogen, fosfor, dan kalsium masing masing sebesar 3,3\%; 6,2\% dan 7,88\%.

\section{Ucapan Terima Kasih}

Tim Pelaksana menyampaikan terima kasih kepada Lembaga Penelitian dan Pengabdian Masyarakat (LPPM) yang telah mendanai kegiatan IbM ini sesuai dengan Surat Perjanjian Pelaksanaan Pengabdian pada Masyarakat Program Ipteks bagi MasyarakatNomor: A.11III/163-S/Pj./LPPM/IV/2021, tanggal 27 April 2021

\section{Referensi}

BPS Kabupaten banyumas. (2020). Kabupaten Banyumas dalam Angka 2020. BPS kabupaten Banyumas: Banyumas

Fakhrudin, M. (2021, Maret 4). Realisasi Investasi di Banyumas Tahun 2020 Capai Rp 1,077 T". Diakses dari https://www.republika.co.id

Ginting, F.B. (2018). Respon Urine Kambing Yang Difermentasi Dengan EM4 Terhadap Produktivitas Stylo (Stylosanthes Guianensis) Dan Kacang Pintoi (Arachis pintol) (Undergraduate Thesis). Diakses dari Universitas Sumatera Utara, Situs Repositori https://repositori.usu.ac.id/ 
Marpaung, AE, Karo, B., \& Tarigan, R. (2016). Pemanfaatan Pupuk Organik Cair Dan Teknik Penanaman Dalam Peningkatan Pertumbuhan Dan Hasil Kentang. J. Hort, 24(1), 49-55. http://dx.doi.org/10.21082/jhort.v24n1.2014

Nur, T., Noor, A.R., \& Elma, M. (2016). Pembuatan Pupuk Organik Cair Dari Sampah Organik Rumah Tangga Dengan Penambahan Bioaktivator EM4 (Effective Microorganisms). Konversi, 5(2), 4451. http://dx.doi.org/10.20527/k.v5i2.4766

Nururrozi, A., Indarjulianto, S., \& Purnamaningsih, H. (2017). Molasses: Dampak Negatif Pada Ruminansia. Jurnal IImu-I/mu Peternakan, 27(2), 25-34. https://doi.org/10.21776/ub.jiip.2017.027.02.04

Nuryani, E., Haryono, G., \& Historiawati. (2019). Pengaruh Dosis dan Saat Pemberian Pupuk P terhadap Hasil Tanaman Buncis (Phaseolus vulgaris L.) Tipe Tegak. Jurnal Imu Pertanian Tropika Dan Subtropika, 4(2), 14-17. http://dx.doi.org/10.31002/vigor.v4i1.1307

Rasmito, A., Hutomo, A., \& Hartono, A. P. (2019). Pembuatan Pupuk Organik Cair dengan Cara Fermentasi Limbah Cair Tahu, Starter Filtrat Kulit Pisang Dan Kubis, dan Bioaktivator EM4. Jurnal IPTEK, 23(1), 55-62. https://doi.org/10.31284/j.iptek.2019.v23i1.496

Sarah, R.H., \& Supriatno. (2016). Pengaruh Pemberian Berbagai Konsentrasi Urin Kambing yang Difermentasi terhadap Pertumbuhan Vegetatif Lada (Piper nigrum L.). Jurnal Ilmiah Mahasiswa Pendidikan Biologi, 1(1), 1-9.

Subandriyo, S., Anggoro, D. D., \& Hadiyanto, H. (2012). Optimasi Pengomposan Sampah Organik Rumah Tangga Menggunakan Kombinasi Aktivator EM4 dan Mol Terhadap Rasio C/N. Jurnal IImu Lingkungan, 10(2), 70. https://doi.org/10.14710/jil.10.2.70-75

Tanti, N., Nurjannah, N., \& Kalla, R. (2019). Pembuatan Pupuk Organik Cair Dengan Cara Aerob. ILTEK: Jurnal Teknologi, 14(2), 2053-2058. https://doi.org/10.47398/iltek.v14i2.415

Widiyanto, A.F., Pratiwi, C.O., \& Yuniarno, S. (2017, November 17). Model Pengelolaan Sampah Rumah Tangga Di Kabupaten Banyumas. Prosiding Seminar Nasional dan Call for Papers, "Pengembangan Sumber Daya Perdesaan dan Kearifan Lokal Berkelanjutan VII"17-18. Diakses dari http://jurnal.Ippm.unsoed.ac.id/

Zahra, F., \& Damanhuri, T.P. (2011). Kajian Komposisi, Karakteristik, dan Potensi Daur Ulang Sampah Di Tpa Cipayung, Depok. Jurnal Teknik Lingkungan, 17(1), 59-69. 